\title{
HUBUNGAN KADAR VITAMIN D SERUM DENGAN KUALITAS HIDUP PADA PASIEN EPILEPSI
}

\author{
THE CORRELATION BETWEEN VITAMIN D SERUM LEVELS WITH QUALITY OF LIFE \\ IN EPILEPSY PATIENT
}

Edith Fitriyana Girsang, * Aris Catur Bintoro, * Dwi Pudjonarko*

\section{ABSTRACT}

Introduction: Epilepsy affects overall health status and decreases the life quality of epilepsy patient. Seizure frequency, seizure type, daily activity disorder, depression and anxiety also affect the quality of life epilepsy patient. Vitamin $D$ is considered as a neurosteroid modulator of nerve excitability and seizure susceptibility. Studies of vitamin D direct role in epilepsy are limited. Nevertheless, some studies show the role of vitamin D as an anticonvulsant that reduces the incidence of seizures.

Aim: To determine the correlation between vitamin D serum levels with quality of life in epilepsy patient.

Method: A cross sectional observational study on people with epilepsy in neurology clinic at Dr. Soeselo Hospital, Slawi, Dr Kariadi Hospital, and Tugurejo Hospital, Semarang in July 2017-January 2018. The quality of life was assessed with Quality of Life in Epilepsy 31 (QOLIE-31). Vitamin D serum levels measured using enzyme-linked immunosorbent assay (ELISA) method. Data were analyzed using Spearman test. Results were considered significant if $p<0.05$.

Results: There was no correlation between vitamin D serum levels with quality of life in epilepsy. There was significant correlation between anxiety with quality of life and there were difference between age group with quality of life.

Discussion: There was no correlation between serum vitamin D levels and quality of life in epilepsy patient.

Keywords: Epilepsy,quality of life epilepsy, vitamin D

\section{ABSTRAK}

Pendahuluan: Epilepsi mempengaruhi status kesehatan secara keseluruhan dan menurunkan kualitas hidup pasien epilepsi. Frekuensi bangkitan, tipe bangkitan, gangguan aktivitas harian, depresi dan ansietas, juga memengaruhi kualitas hidup pasien epilepsi. Vitamin D dianggap neurosteroid, sebagai modulator eksitabilitas saraf dan kerentanan bangkitan. Bukti langsung untuk peran vitamin D dalam epilepsi terbatas. Namun beberapa penelitian menunjukkan peran vitamin D sebagai antikonvulsan yang mengurangi kejadian bangkitan.

Tujuan: Mengetahui hubungan kadar vitamin D serum dengan kualitas hidup pada pasien epilepsi.

Metode: Penelitian potong lintang terhadap pasien epilepsi yang berobat ke Poliklinik Saraf RSUD Dr. Soeselo, Slawi, RSUP Dr. Kariadi, Semarang, dan RS Tugurejo, Semarang pada bulan Juli 2017-Januari 2018. Kualitas hidup dinilai menggunakan kuesioner Quality of Life in Epilepsy 31 (QOLIE-31), pengukuran kadar vitamin D serum menggunakan metode enzyme-linked immunosorbent assay (ELISA). Data dianalisis dengan uji Spearman, hasil dianggap bermakna jika $\mathrm{p}<0,05$.

Hasil: Tidak didapatkan hubungan antara kadar vitamin D serum dengan kualitas hidup serta domainnya pada pasien epilepsi. Didapatkan hubungan yang bermakna antara ansietas dengan kualitas hidup dan antara kelompok usia dengan kualitas hidup.

Diskusi: Tidak terdapat hubungan bermakna antara kadar vitamin D serum dengan kualitas hidup pada pasien epilepsi.

Kata kunci: Epilepsi, kualitas hidup, vitamin D

*Bagian Neurologi FK Universitas Diponegoro/RSUP Dr. Kariadi, Semarang. Korespondensi: edith.girsang@gmail.com.

\section{PENDAHULUAN}

Epilepsi merupakan gangguan saraf kronis atau kelompok gangguan dengan karakteristik bangkitan yang berulang (dua atau lebih) biasanya saat muncul tidak dapat diprediksi, tanpa ada faktor yang memprovokasi. ${ }^{1}$ Epilepsi menyerang semua usia dan diderita baik oleh laki-laki dan perempuan. ${ }^{2}$ Diperkirakan terdapat 2,4 juta orang didiagnosis dengan epilepsi tiap tahun. ${ }^{3}$

World Health Organization (WHO) mendefinisikan kualitas hidup sebagai persepsi individu tentang keadaan kehidupan dalam konteks budaya dan sistem nilai, serta kaitannya dengan tujuan, harapan, standar, dan kekhawatiran. ${ }^{4}$ Pasien epilepsi berisiko tinggi memiliki kualitas hidup yang buruk. Epilepsi merupakan kondisi kronis dengan 
berdampak multidimensi pada fungsi psikososial, sehingga kualitas hidupnya perlu diukur. ${ }^{5}$

Faktor-faktor klinis, seperti seringnya frekuensi bangkitan dan durasi penyakit yang lama, memiliki pengaruh bermakna pada kualitas hidup. Usia lanjut, jenis kelamin perempuan, dan tingkat pendidikan rendah adalah faktor demografi yang berkorelasi kuat dengan kualitas hidup yang buruk. ${ }^{6}$ Epilepsi juga memengaruhi status kesehatan secara keseluruhan dan menurunkan kualitas hidup penderitanya. Frekuensi bangkitan, tipe bangkitan, gangguan aktivitas harian, depresi dan ansietas, juga memengaruhi kualitas hidup atau psikososial pasien epilepsi. ${ }^{7-9}$

Vitamin D merupakan hormon sekosteroid; memiliki molekul mirip dengan steroid tetapi terdapat dua cincin-B karbon (yang terdapat pada empat cincin steroid) tidak menyatu, ikatan terputus antara atom C9 dan $\mathrm{C} 10$ yang mekanismenya melalui reseptor nuklear (vitamin $D$ receptor/VDR), menginduksi transkripsi sejumlah besar gen dan memengaruhi homeostasis dari kalsium/fosfor serta kesehatan tulang. ${ }^{10-11}$ Vitamin D juga memengaruhi fungsi selular seperti proliferasi sel, diferensiaisi sel dan kelangsungan hidup berbagai tipe sel hampir di semua jaringan, termasuk sistem saraf. ${ }^{10}$ Enzim katabolisasi dari 1,25-dihydroxyvitamin $\mathrm{D}$ (calcitriol) diregulasi di otak. Berdasarkan struktur molekul, bioaktivasi dalam sistem saraf dan mekanisme kerja vitamin D dianggap sebagai sebuah neurosteroid.

Neurosteroid semakin banyak diakui sebagai modulatoreksitabilitassarafdankerentananbangkitan. Bukti langsung untuk peran vitamin D dalam epilepsi terbatas. Namun terdapat penelitian yang meneliti efek suplementasi vitamin D pada kontrol bangkitan. Pada kelompok yang diberikan suplemen vitamin D2 (4000 IU/hari) terjadi pengurangan bangkitan rata-rata $30 \%$, sedangkan pada kelompok kontrol tidak ada pengurangan bangkitan yang bermakna. ${ }^{12}$ Hollo dkk melakukan penelitian yang mengukur dan memperbaiki tingkat defisiensi kadar serum $25(\mathrm{OH})$ D dengan menambahkan vitamin D3 pada 13 pasien epilepsi yang resisten terhadap terapi. Bangkitan sebelum dan sesudah awitan pengobatan dinilai dan didapatkan pengurangan bangkitan yang signifikan sebesar $40 \% .^{12}$

Penyebab utama defisiensi vitamin D adalah kurangnya paparan sinar matahari yang merupakan sumber vitamin D paling banyak. Hanya sedikit makanan yang mengandung vitamin $\mathrm{D}$, dan makanan yang difortifikasi dengan vitamin $\mathrm{D}$ sering tidak adekuat untuk memenuhi kebutuhan vitamin D baik pada anak-anak maupun dewasa. Usia lanjut, obesitas dan obat antiepilepsi (OAE) juga merupakan penyebab umum defisiensi vitamin D. ${ }^{13}$ Penggunaan OAE dalam jangka waktu yang lama terutama politerapi meningkatkan katabolisme dari vitamin D melalui induksi sistem sitokrom P450. ${ }^{14}$ Obat antiepilepsi menyebabkan kadar 25(OH)D/25hydroxivitamin D (calcidiol) menjadi rendah dan terkait dengan efek samping pada tulang. ${ }^{15}$

\section{TUJUAN}

Mengetahui hubungan kadar vitamin D serum dengan kualitas hidup pada penderita epilepsi, serta faktor-faktor yang memengaruhinya.

\section{METODE}

Penelitian potong lintang terhadap pasien epilepsi yang berobat ke Poliklinik Saraf RSUD Dr. Soeselo, Slawi, RSUP Dr. Kariadi, Semarang, dan RS Tugurejo, Semarang pada bulan Juli 2017-Januari 2018. Kriteria inklusi adalah pasien epilepsi berusia 17-60 tahun. Adapun kriteria eksklusi yaitu pasien yang memiliki keterbatasan fisik atau mental yang tidak memungkinkan mereka untuk menyelesaikan kuesioner Quality of Life in Epilepsy 31 (QOLIE-31).

Data primer diperoleh dari kuesioner yang meliputi data demografi, lama menderita epilepsi, jenis bangkitan, depresi, dan ansietas. Penilaian depresi menggunakan kuesioner The Neurological Disorders Depression Inventory for Epilepsy (NDDI-E), ansietas menggunakan Hamilton Anxiety Rating Scale (HAM-A), dan kualitas hidup dinilai dengan QOLIE-31 yang telah divalidasi ke dalam Bahasa Indonesia. ${ }^{16}$ Quality of Life in Epilepsy 31 terdiri dari tujuh domain, yaitu kekhawatiran akan serangan, kualitas hidup secara umum, kesejahteraan emosional, energi/fatigue, fungsi kognitif, efek samping obat, dan fungsi sosial. Skor terendah 0 dan tertinggi 100, semakin tinggi skor semakin baik kecenderungan kualitas hidup. ${ }^{16-17}$

Kadar vitamin D serum ditentukan dengan mengukur konsentrasi total 25 -hidroksi vitamin D menggunakan metode enzyme-linked immunosorbent 
Tabel 1. Karakteristik Subjek Pasien Epilepsi $(n=40)$

\begin{tabular}{|c|c|}
\hline Variabel & n (\%) \\
\hline \multicolumn{2}{|l|}{ Jenis kelamin } \\
\hline - Laki-laki & $19(47,5)$ \\
\hline - Perempuan & $21(52,5)$ \\
\hline \multicolumn{2}{|l|}{ Kategori usia } \\
\hline - Remaja (17-25 tahun) & $10(25)$ \\
\hline - Dewasa (26-45 tahun) & $25(62,5)$ \\
\hline - Lansia (46-65 tahun) & $5(12,5)$ \\
\hline \multicolumn{2}{|l|}{ Pendidikan } \\
\hline - $\leq 9$ tahun & $20(50)$ \\
\hline - $>9$ tahun & $20(50)$ \\
\hline \multicolumn{2}{|l|}{ Durasi menderita epilepsi } \\
\hline - $1-6$ bulan & $3(7,5)$ \\
\hline - $>6-12$ bulan & $3(7,5)$ \\
\hline - $>12$ bulan & $34(85)$ \\
\hline \multicolumn{2}{|l|}{ Jumlah terapi epilepsi } \\
\hline - Monoterapi & $9(22,5)$ \\
\hline - Politerapi & $31(77,5)$ \\
\hline \multicolumn{2}{|l|}{ Serangan } \\
\hline - Terkontrol & $27(67,5)$ \\
\hline - Tidak terkontrol & $13(32,5)$ \\
\hline \multicolumn{2}{|l|}{ Jenis bangkitan } \\
\hline - Umum & $36(90)$ \\
\hline - Fokal & $4(10)$ \\
\hline \multicolumn{2}{|l|}{ Kadar vitamin D serum } \\
\hline - Normal & $15(37,5)$ \\
\hline - Rendah & $25(62,5)$ \\
\hline \multicolumn{2}{|l|}{ Depresi } \\
\hline - $\mathrm{Ya}$ & 0 \\
\hline - Tidak & $40(100)$ \\
\hline \multicolumn{2}{|l|}{ Ansietas } \\
\hline - Ringan & $39(97,5)$ \\
\hline - Sedang sampai berat & $1(2,5)$ \\
\hline
\end{tabular}

assay (ELISA). Kadar tersebut dikatakan normal bila di atas $20 \mathrm{ng} / \mathrm{mL}$ dan rendah bila di bawahnya. Penelitian ini telah mendapat ethical clearance dari Komisi Etik Fakultas Kedokteran Universitas Diponegoro, Semarang.

Data diolah menggunakan SPSS for Window versi 21. Korelasi antar variabel dengan distribusi normal diuji menggunakan uji Pearson. Uji Spearman bagi data distribusi tidak normal untuk mengetahui hubungan kadar vitamin D serum dengan kualitas
Tabel 2. Uji Komparatif Karakteristik Subjek dengan Kualitas Hidup $(n=40)$

\begin{tabular}{|c|c|c|}
\hline Variabel & Rerata \pm SB & $\mathbf{p}$ \\
\hline \multicolumn{3}{|l|}{ Jenis kelamin } \\
\hline - Laki-laki & $70,21 \pm 16,16$ & $0,523^{*}$ \\
\hline - Perempuan & $71,39 \pm 14,52$ & \\
\hline \multicolumn{3}{|c|}{ Jumlah terapi epilepsi } \\
\hline - Monoterapi & $75,01 \pm 15,03$ & $0,845^{\star}$ \\
\hline - Politerapi & $69,62 \pm 15,19$ & \\
\hline \multicolumn{3}{|l|}{ Pendidikan } \\
\hline - $\leq 9$ tahun & $73,35 \pm 17,12$ & $0,300^{*}$ \\
\hline - $<9$ tahun & $68,32 \pm 12,79$ & \\
\hline \multicolumn{3}{|l|}{ Kategori usia } \\
\hline - Remaja & $69,02 \pm 12,47$ & $\mathbf{0 , 0 3 3 ^ { \S }}$ \\
\hline - Dewasa & $68,31 \pm 15,10$ & \\
\hline - Lansia & $87,07 \pm 11,67$ & \\
\hline \multicolumn{3}{|l|}{ Serangan } \\
\hline - Terkontrol & $69,34 \pm 15,06$ & $0,536^{*}$ \\
\hline - Tidak terkontrol & $73,93 \pm 15,40$ & \\
\hline \multicolumn{3}{|l|}{ Jenis bangkitan } \\
\hline - Umum & $71,65 \pm 15,37$ & $0,427^{*}$ \\
\hline - Fokal & $63,47 \pm 11,78$ & \\
\hline
\end{tabular}

hidup. Uji komparatif numerik yang berdistribusi normal dengan T test; jika lebih dari dua kelompok yang berdistribusi normal dengan Uji One Way ANOVA. Hasil dianggap bermakna apabila $p<0,05$.

HASIL

Didapatkan 40 subjek (Tabel 1) dengan proporsi yang hampir sama antara laki-laki dan perempuan, serta rerata usia $33,05 \pm 10,85$ tahun. Mayoritas subjek menderita epilepsi $>12$ bulan (85\%) dengan jenis bangkitan umum (90\%), mendapat politerapi $(77,5 \%)$ dan serangan terkontrol $(67,5 \%)$. Kadar vitamin D subjek kebanyakan rendah $(62,5 \%)$, tidak ada subjek yang mengalami depresi, dan hanya sebagian kecil yang mengalami ansietas sedang sampai berat $(2,5 \%)$.

Tabel 2 menunjukkan uji komparatif antara karakteristik subjek dengan kualitas hidup berdasarkan skor rerata QOLIE-31. Tidak didapatkan perbedaan antara berbagai karakteristik subjek 


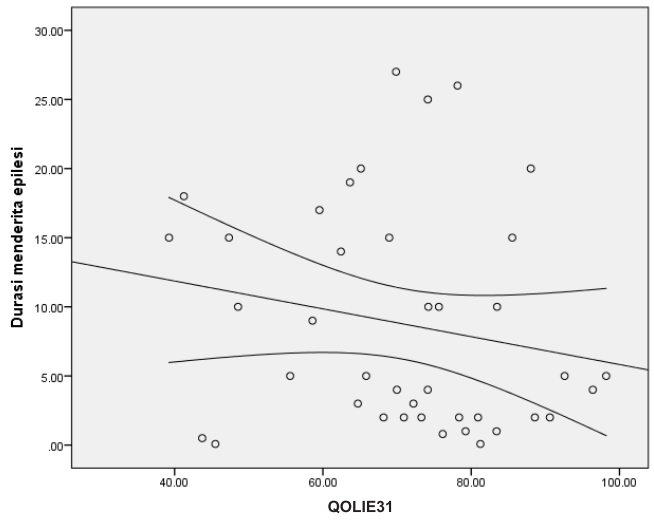

a. Spearman rho $(r)=-0,132, p=0,418$

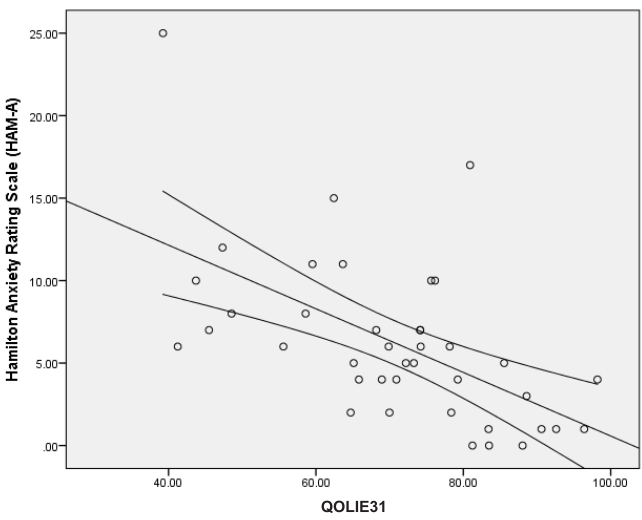

b. Spearman rho $(r)=-0,638 \mathrm{p}=0,0001$

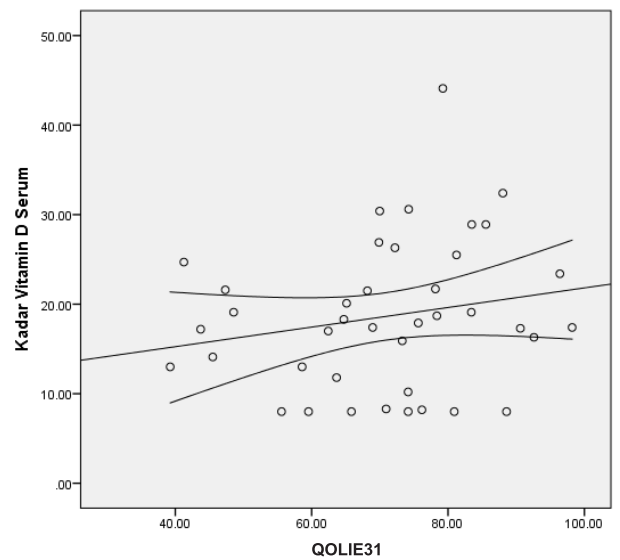

c. Spearman rho $(r)=0,228 \mathrm{p}=0,342$

Gambar 1. Hubungan a. Durasi Menderita Epilepsi, b. Ansietas, dan c. Kadar Vitamin D Serum dengan Kualitas Hidup pada Pasien Epilepsi

dengan kualitas hidup, kecuali lansia mempunyai kualitas hidup yang lebih buruk dari remaja dan dewasa $(p=0,033)$.

Median durasi menderita epilepsi adalah 5,0 $(0,08-27)$ tahun. Hasil uji Spearman tidak didapatkan hubungan bermakna antara durasi pengobatan dan jumlah jenis OAE dengan kualitas hidup (Gambar 1a dan b). Didapatkan hubungan yang bermakna antara ansietas dengan kualitas hidup pasien epilepsi (Gambar 1b).

Median kadar vitamin D serum pada subjek penelitian ini adalah di bawah normal, yaitu 17,65 (8,00-44,10)ng/mL dengan rerata skor QOLIE-31 $(70,839 \pm 13,136)$. Adapun skor QOLIE-31 terendah adalah 39,25 dan tertinggi 98,20. Tidak didapatkan hubungan yang bermakna antara kadar vitamin D serum dengan kualitas hidup pasien epilepsi (Gambar 1c), maupun antara kadar vitamin D dengan seluruh domain QOLIE-31 (Tabel 3).
Tabel 3. Hubungan Kadar Vitamin D Serum dengan Domain QOLIE-31

\begin{tabular}{lcc}
\hline \multirow{2}{*}{\multicolumn{1}{c}{ Domain QOLIE-31 }} & \multicolumn{2}{c}{ Kadar Vitamin D } \\
\cline { 2 - 3 } & $\mathbf{r}$ & $\mathbf{p}$ \\
\hline Kekhawatiran akan bangkitan & 0,027 & $0,870^{*}$ \\
Kualitas hidup keseluruhan & 0,121 & $0,457^{*}$ \\
Kesehatan emosional & 0,159 & $0,326^{*}$ \\
Energi/kelelahan & 0,176 & $0,218^{* *}$ \\
Fungsi kognitif & 0,146 & $0,370^{* *}$ \\
Efek obat & $-0,037$ & $0,822^{*}$ \\
Fungsi sosial & 0,241 & $0,134^{*}$ \\
\hline
\end{tabular}

*Uji Pearson; **uji Spearman.

\section{PEMBAHASAN}

Penelitian Brabcova dkk, perempuan lebih cemas akan terjadinya bangkitan dan lebih rentan secara emosional atau terkait dengan masalah dengan kehamilan. ${ }^{18-19}$ Penelitian di Taiwan menunjukkan kualitas hidup perempuan lebih rendah terutama 
pada kecemasan akan bangkitan, fungsi kognitif dan efek pengobatan. Mereka berperan sebagai pengasuh keluarga, bertanggung jawab merawat orang sakit atau cacat sehingga adanya epilepsi dikhawatirkan dapat mengganggu kemampuan dalam menyelesaikan fungsi tersebut. ${ }^{20}$

Pada penelitian ini tidak didapatkan perbedaan kualitas hidup dengan kelompok jenis kelamin, sebagaimana Brustera-Bota dkk. ${ }^{21}$ Hal ini dapat disebabkan karena mayoritas subjek penelitian ini yaitu $76,2 \%$ perempuan dan $57,9 \%$ laki-laki mempunyai serangan yang terkontrol.

Kualitas hidup pada usia lanjut penelitian ini lebih rendah daripada usia muda. Pada usia muda epilepsi mempunyai pengaruh yang besar akan pekerjaan dan hubungan dengan teman dekat serta keluarga. Aktivitas sosial lebih banyak didapatkan pada usia muda dibanding usia lanjut, karena pada usia lanjut sering terdapat ketakutan akan terjadinya bangkitan saat beraktivitas. ${ }^{22}$ Selain itu kualitas hidup pada pasien epilepsi usia lanjut juga dipengaruhi oleh efek samping OAE, frekuensi bangkitan, komorbiditas, dan ketergantuan pada bantuan dari orang lain. ${ }^{22-23}$

Pada penelitian yang dilakukan di Kenya pasien epilepsi berpendidikan rendah mempunyai kualitas hidup yang lebih rendah. Hal ini mencerminkan pasien epilepsi yang berpendidikan tinggi mempunyai kemampuan yang lebih terampil sehingga mempunyai kesempatan yang lebih baik, lebih mudah untuk mengakses pelayanan kesehatan, dan tidak menjadikan penyakitnya sebagai alasan tidak bekerja. ${ }^{24}$ Namun, pada penelitian ini tidak didapatkan perbedaan kualitas hidup antara kelompok pendidikan. Walaupun tidak bermakna, subjek epilepsi dengan pendidikan $\leq 9$ tahun mempunyai rerata skor QOLIE-31 yang lebih tinggi, yaitu 75,35 dibandingkan subjek dengan pendidikan $>9$ tahun, yaitu 68,32 . Hal ini dapat disebabkan adanya kemudahan untuk akses kesehatan dan diperlukan jumlah subjek yang lebih besar.

Berbeda dengan penelitian sebelumnya, pasien epilepsi yang mendapat OAE politerapi mempunyai kualitas hidup yang lebih rendah terkait dengan rendahnya pengendalian bangkitan. ${ }^{25}$ Pada penelitian ini $81,3 \%$ subjek dengan serangan terkontrol mendapat OAE politerapi sehingga tidak didapatkan perbedaan kualitas hidup di antara kelompok jumlah jenis OAE.

Kualitas hidup yang lebih rendah didapatkan pada pasien epilepsi dengan durasi epilepsi lebih dari 15 tahun, karena terdapat penurunan aktivitas harian dan kognisi. ${ }^{26}$ Pada penelitian ini terdapat kecenderungan pasien epilepsi dengan durasi epilepsi yang semakin lama mempunyai kualitas hidup yang lebih rendah (Gambar 1a), namun tidak didapatkan hubungan bermakna, diperlukan jumlah subjek yang lebih besar.

Tidak didapatkan perbedaan kualitas hidup pada terkontrol tidaknya serangan, serta frekuensi dan jenis bangkitan dalam penelitian ini, seperti halnya penelitian Brusturean-Bota dan Akdemir dkk. ${ }^{21,27}$ Namun penelitian lain melaporkan bahwa kualitas hidup lebih rendah pada pasien dengan bangkitan fokal, diikuti oleh serangan bangkitan general tonik. ${ }^{26}$ Pada penelitian ini jumlah subjek dengan jenis bangkitan fokal dan serangan tidak terkontrol sedikit sehingga tidak didapatkan perbedaan yang bermakna.

Sekitar 50 sampai $60 \%$ pasien epilepsi kronis setidaknya memiliki satu gangguan mood termasuk depresi dan ansietas. ${ }^{28}$ Ansietas adalah gangguan kejiwaan paling umum kedua pada pasien epilepsi. Pada suatu penelitian dari layanan spesialis neuropsikiatri untuk pasien epilepsi sekitar 27\% mengalami ansietas. Pasien epilepsi dengan ansietas sedang sampai rendah mempunyai kualitas hidup yang lebih rendah. ${ }^{29-30}$

Pada penelitian ini juga didapatkan hubungan yang bermakna antara kualitas hidup dengan ansietas, semakin tinggi skor ansietas semakin rendah kualitas hidup pasien epilepsi (Gambar 1b). Lobus frontal, temporal dan daerah limbik terkait dengan patogenesis biologi ansietas pada pasien epilepsi. Abnormalitas struktur, jalur monoamin, metabolisme glukosa serebral, aksis hipotalamus-hipofisisadrena, dan interleukin-1b juga merupakan penyebab ansietas pada epilepsi. Begitu pula struktur anatomi amigdala dan hipokampus, asam $\gamma$-aminobutirik, serta serotonin. ${ }^{31}$ Kekhawatiran akan terjadinya bangkitan, keadaan kualitas hidup keseluruhan, emosional, rasa lelah, fungsi kognitif dari pasien epilepsi merupakan faktor yang berperan akan adanya ansietas. 
Vitamin D pada beberapa penelitian dikatakan mempunyai efek sebagai antikonvulsan yang dapat mengurangi terjadinya bangkitan, selain penting untuk absorpsi kalsium dan mempertahankan kesehatan tulang. ${ }^{11}$ Vitamin D3 yang sampai ke hipokampus meningkatkan ambang batas bangkitan yang diinduksi secara kimia serta meningkatkan kerentanan bangkitan pada reseptor vitamin $\mathrm{D}$ tikus. ${ }^{12}$ Dengan berkurangnya serangan, kualitas hidup pada pasien epilepsi menjadi lebih baik. Namun, mekanisme bagaimana vitamin D memberikan manfaat efek antiepilepsi masih harus dieksplorasi.

Reseptor vitamin D adalah 1-alfa-hidroksilase, enzim yang menghasilkan 1,25 (OH) D (bentuk aktif dari vitamin D), didistribusikan secara luas di otak. Efek vitamin D di sistem saraf pusat dimediasi baik oleh aksi kalsemik dan non-kalsemik. Yang terakhir termasuk perubahan ekspresi gen dalam menanggapi pengikatan 1,25 $(\mathrm{OH})$ D ke reseptor vitamin D. ${ }^{12}$ Pada penelitian ini tidak didapatkan hubungan antara vitamin D dengan kualitas hidup pada pasien epilepsi. Vitamin D tidak mengurangi kejadian bangkitan pada pasien epilepsi atau mencegah efek sampaing OAE. ${ }^{32}$ Pemberian suplementasi vitamin D pada 160 pasien epilepsi yang mengalami defisiensi vitamin D juga tidak mengurangi kejadian bangkitan. ${ }^{33}$ Pada penelitian ini subjek dengan serangan terkontrol lebih banyak mengalami defisiensi vitamin $\mathrm{D}$, sehingga tidak didapatkan perbedaan antara kadar vitamin D serum dengan terkontrol tidaknya serangan sehingga tidak memengaruhi kualitas hidup.

Penelitian ini mempunyai keterbatasan yaitu tidak adanya kriteria inklusi minimal lamanya menderita epilepsi, sehingga dapat terjadi bias pada pasien epilepsi yang baru terdiagnosis, lebih banyak subjek yang terkontrol dan mendapat OAE politerapi, hanya sedikit yang mengalami bangkitan fokal, mayoritas subjek mengalami defisiensi vitamin $\mathrm{D}$, dan peneliti tidak memperhatikan asupan nutrisi keseharian subjek, sehingga tidak diketahui asupan makanan pasien yang dapat memengaruhi kadar vitamin D.

\section{KESIMPULAN}

Tidak terdapat hubungan antara kadar vitamin D serum dan kualitas hidup pada pasien epilepsi. Tidak didapatkan hubungan antara jenis kelamin, pendidikan, jumlah jenis OAE, lama menderita epilepsi, frekuensi serangan, dan bentuk serangan dengan kualitas hidup pada pasien epilepsi. Kualitas hidup pada pasien usia lanjut lebih rendah dan pasien epilepsi yang mengalami ansietas mempunyai kualitas hidup yang lebih rendah.

\section{DAFTAR PUSTAKA}

1. Ali N, Nabi M. The prevalence, incidence and etiology of epilepsy. Int J Clin Exp Neurol. 2014;2(2):29-39.

2. Neligan A, Sander L, Sander JW. The Epidemiology of epilepsy revisited. Curr Opin Epilepsy. 2012;16(2):165-70.

3. Trinka E, Kwan P, Lee B, Dash A. Epilepsy in Asia: disease burden, management barriers, and challenges. Epilepsia. 2018;2018:1-15.

4. Gholami A, Salarilak S, Lotfabadi P, Kiani F. Quality of life in epileptic patients compared with healthy people. Med J Islam Repub Iran. 2015;29(388):1-7.

5. Patel P. An Analysis of pharmacological management of epilepsy and its effect on quality of life. J Basic Clin Pharm. 2017;8:44-8.

6. Staniszewska A, Kurkowska-Jastrzebska, TarchalskaKrynska B. Quality of life in patients with epilepsy. J Public Heal Nurs Edical Rescue. 2015;157(3):20-6.

7. Chung $\mathrm{C}$, Kim H, Lee S, Yoon S, Kho H, Oh J, dkk. Factors affecting the quality of life in patients with epilepsy in Seoul, South Korea. Acta Neurol Scand. 2003;108(6):428-34.

8. Jacoby A, Snape D, Lane S, Baker GA. Self-reported anxiety and sleep problems in people with epilepsy and their association with quality of life. Epilepsy Behav. 2015;43:149-58.

9. Sadr SS, Javanbakht J, Javidan AN, Ghaffarpour M. Descriptive epidemiology: prevalence, incidence, sociodemographic factors, socioeconomic domains, and quality of life of epilepsy: an update and systematic review. Arch Med Sci. 2018;14(4):71724.

10. Latimer CS, Brewer LD, Searcy JL, Chen K, Popovi J, Kraner SD, dkk. Vitamin D prevents cognitive decline and enhances hippocampal synaptic function in aging rats. PNAS. 2014;111(41):4359-66.

11. Hollo A, Clemens Z, Lakatos P. Epilepsy and vitamin D. Int J Neurosci. 2014;124(6):387-93.

12. Hollo A, Kamondi A, Lakatos P, Szucs A. Correction of vitamin D deficiency improves seizure control in epilepsy: a pilot study. Epilepsy Behav. 2012;24(1):131-3.

13. Holick MF. The vitamin D deficiency pandemic: approaches for diagnosis, treatment and prevention. Rev Endocr Metab Disord. 2017;18(2):153-65. 
14. Sreedharan $M$, Devadathan $K$, Kunju PM, Sasidharan B, Pillai JP, Amma MAV, dkk. Vitamin $\mathrm{D}$ deficiency in ambulant children on carbamazepine or sodium valproate monotherapy. Indian Pediatr. 2018;55(4):307-10.

15. Fernandez H, Patel T. Vitamin D supplementation for bone health in adults with epilepsy: a systematic review. Epilepsia. 2018;59(4):1-12.

16. Gunadharma S, Nurimaba N, Rochayatin O. Uji kesahihan dan keandalan quality of life in epilepsy inventory (QOLIE-31) versi bahasa Indonesia. Neurona. 2015;32(3):1-9.

17. Saadi A, Patenaude B, Mateen FJ. Quality of life in epilepsy-31 inventory (QOLIE-31) scores: a global comparison. Epilepsy Behav. 2016;65:13-7.

18. Brabcova D, Kohout J. What are the predictors of quality of life of people with epilepsy? J Neurosci Rural Pract. 2013;4(5):5-7.

19. Tedrus GM, Fonseca LC, Carvalho RM. Epilepsy and quality of life: socio-demographic and clinical aspects, and psychiatric co-morbidity. Arq Neuropsiquiatr. 2012;71(6):385-91.

20. Chen H, Tsai Y, Hsi M, Chen J. Factors affecting quality of life in adults with epilepsy in Taiwan: a cross-sectional, correlational study. Epilepsy Behav. 2016;58:26-32.

21. Brusturean-Bota E, Coada CA, Buzoianu AD. Assessment of quality of life in patients with epilepsy. Hum Vet Med Int J Bioflux Soc. 2013;5(3):82-7.

22. May TW, Pfafflin M, Brandt C, Furatsch N, Schmitz B, Wandschneider B, dkk. Epilepsy in the elderly: restrictions, fears, and quality of life. Acta Neurol Scand. 2015;(10):176-86.

23. Baranowski CJ. The quality of life of the elderly with epilepsy: a systematic review. Seizure. 2018;60:190-7.

24. Kinyanjui DW, Kathuku DM, Mburu JM. Quality of life among patients living with epilepsy attending the neurology clinic at Kenyatta national hospital, Nairobi, Kenya: a comparative study. Health Qual Life Outcomes. 2013;11(1):98-107.

25. George J, Kulkarni C, Epilepsy CC, Sarma GR. Antiepileptic drugs and quality of life in patients with epilepsy: a tertiary care hospital-based study. Value Heal Reg Issues. 2015;6:1-6.

26. Shetty PH, Naik RK, Saroja AO, Punith K. Quality of life in patients with epilepsy in India. J Neurosci Rural Pr. 2011;2(1):33-40

27. Akdemir V, Sut N, Guldiken B. Factors affecting the quality of life in drug-resistant epilepsy patients. Acta Neurol Belg. 2016;116(4):513-8.

28. Beyenburg S, Mitchell AJ, Schmidt D, Elger CE, Reuber M. Anxiety in patients with epilepsy: systematic review and suggestions for clinical management. Epilepsy Behav. 2005;7(2):161-71.

29. Gur-ozmen S, Leibetseder A, Cock HR, Agrawal N, Von-Oertzen TJ. Screening of anxiety and quality of life in people with epilepsy. Seizure Eur J Epilepsy. 2017;45:107-13.

30. Osman A, Seri S, Cavanna AE. Clinical characteristics of patients with epilepsy in a specialist neuropsychiatry service. Epilepsy Behav. 2016;58:44-7.

31. Izci F, Findikli E, Camkurt MA, Tuncel D, Sahin M. Impact of aggression, depression, and anxiety levels on quality of life in epilepsy patients. Neuropsychiatr Dis Treat. 2016;12:2595-603.

32. Ranganathan LN, Ramaratnam S. Vitamins for epilepsy (Review). Cochrane Libr. 2009;(2).

33. Tombini M, Palermo A, Assenza G, Pellegrino G, Benvenga A, Campana C, dkk. Calcium metabolism serum markers in adult patients with epilepsy and the effect of vitamin D supplementation on seizure control. Seizure Eur J Epilepsy. 2018;58:75-81. 